\title{
The Institute of the Mari Ethnos Family in the XVIII-XIX Centuries
}

\author{
Nikolay I. Petrenko ${ }^{1} \&$ Aleksey V. Efremov ${ }^{1}$ \\ ${ }^{1}$ Mari State University, Yoshkar-Ola, Russia \\ Correspondence: Nikolay I. Petrenko, Petrova Street, 18-a, apartment 117, Yoshkar-Ola, 424038, Russia.
}

$\begin{array}{lcc}\text { Received: February 21, } 2015 & \text { Accepted: March 15, } 2015 & \text { Online Published: April 29, } 2015 \\ \text { doi:10.5539/res.v7n8p201 } & \text { URL: http://dx.doi.org/10.5539/res.v7n8p201 }\end{array}$

\begin{abstract}
This article is devoted to the analysis of the norms of a customary law of the Mari peasants in the XVIII-XIX centuries, which are regulating the institute of the matrimonial relations. During this period the regulation of the legal relations between the rural population was carried out on the basis of official laws. The process of registration of the Russian legislation was happened with the help of certain influence of a customary law and allowed an application in legal proceedings of local legal customs. It allows to create an idea of the family rights of the people of the Mari region, who were under the influence of the Russian legislation, which was entered after accession of the territory of Central Volga area to the Russian state in the middle of the XVI century. We investigate the legal awareness of Mari peasants, the role of the customary law in the form of law-making community and its institutes. It is making the conclusion about the value of the rural community containing rich actual material about the real life of the Mari village of the Volga region.
\end{abstract}

Keywords: Ethnicity Marie, the common law, family relations, lynching, snokhachestvo, paganism

\section{Introduction}

The XVIII century occupies a special place in the Russian history as a period of establishment and strengthening of the absolute monarchy, the transformation of the Russian state in the Russian Empire, significant changes in the socio-political and socio-economic life of the country. Considerable space in the process of transformation was played the reform of legislation. It also fixed the changes taking place in society. The non-Russian population also couldn't avoid it. Many orders were multifunctional in its significance, affecting both the various aspects of the Russian society life. That's all gives an idea of the main directions of the legislative activity in the Russian government, and consequently-its policies.

Social and legal status of east and north-east foreigners of European Russia until the XVIII century was not as different as the rest of the population of the province. The moderate approach in relation to the local population oriented Russian government on a combination of peace and punitive measures. Peaceful methods were aimed at the integration of the conquered peoples in the Russian state. This approach is not new and was based on the traditional Russian policy to involve neighboring nations to their side. Furthermore, in XVII there were not taken any successive attempts to isolate foreigners from among of the rest of the serving and non-serving population of the state. However, in the first quarter of XVIII Russian authorities made a decisive step towards the isolation of foreigners in particular, inter alia, the Russian population layer.

XVIII century is the third stage of development of conditional Provincial Office in the Mari region. It is characterized by gradual weakening and temporary replacement system Office of the Voivode as it wasn't fit for purpose, during the reforms of Peter the first quarter of XVIII century and at the same time, a new demand for the second and third quarters of the XVIII century, which ended its liquidation during the provincial reform era of "enlightened" absolutism of the Russian Empress Catherine II the Great. One of the features of the Provincial Office in the Mari region in 1700-1710 years and 1728-1781 years, in addition to existing features in common, typical for the whole territory of the Russian state, was expressed in the fact that at this stage to keep a former administrative-territorial units-counties included in this or that province and the province.

Difficulties in understanding people's legal customs that existed among the peasants, are largely in the fact that their lives, especially in the post-reform period, was under police petty administrative tutelage of the government bureaucracy. A kind of "analysis" violations of everyday life among the peasants was quite commonplace. They, along with their village "bosses" and the concept of the investigation carried out, which due to the fact that the peasants were well aware of local conditions of life, the nature of the relationships among the villagers, as well as 
the personal qualities of participants in the case, were often very effective. Regulation of legal relations of rural residents was carried out on the basis of official laws. By the way the content of the latter was not without various ambiguities and contradictions, but at the same time it was more ordered, unlike the unwritten folk customs.

\section{Results and Discussions}

Regulation of the legal relations on the unwritten folk customs in the life of Mari ethnos are still poorly studied in historical and ethnographic literature. The available researches on this subject (Iznoskov, 1868) include only descriptions of separate legal views and legal customs of Mari peasants and don't give enough knowledge about that value, which the normal-precepts of law have usually had in pre-revolutionary life of the region. The fact of the existence of customary law was an expression of self-governing character of the peasant life, i.e. it was a consequence of the vital functions of a rural community.

There were existed legal views of peasants "they were not in the form of a systematic collection or code, but as scattered, more heartfelt than thoughtful concepts" (Iznoskov, 1868). Such opinions that were characterized inconsistency, uncertainty and legal views of peasants, including customary law, also were expressed in the Soviet scientific literature. Existing studies on this subject include only descriptions of individual legal views and legal customs of Mari peasants and give almost no idea of the importance that had the customary law in pre-revolutionary life of the region. The fact of existence of a customary law was an expression of self-administrative character of peasants' life, it means, that it was a consequence of activity of a rural community. A. A. Pushkarenko wrote that "even in close to the peasants areas, the rights of the peasants were not complete and accurate. And this applies not only to the Scriptures, but also customary law, which oral form of existence was combined with the general uncertainty of the language, opens up great possibilities for arbitrary interpretation" (Pushkarenko, 1984). The majority of the mixed ethnic population kept the locality, both in terms of Russian neighbors, and with respect to Russian authorities. Moreover, according to G. I. Peretyatkovich, many of the foreigners, together with Russian took an active part in the settlement of the Kazan region (Peretyatkovich, 1882). Moreover, the process of registration of the legislation in the Russian state did not occur without a certain influence of the customary law and in some cases it allowed to use in the township proceedings of local legal customs.

More complex role of rural communities is represented in matters concerning to the family relations, marriage and its cancellation, violation of family life, the moral view of women, etc. The community in these cases acted both by the direct intervention and by customs and traditions, which were developed during the centuries. The functions of the governor by the decision of the court cases were quite extensive. Judicial activity in Russia in the middle of XVIII century didn't include a specific industry, as it was closely associated with the administrative and police powers.

A voivod also had to deal with a variety of unscrupulous, sometimes very ancient in its tradition, things. Among the Mari population there was practiced traditional in many nations- ancient "snitch" of brides. So, In August in the old Epiphany village "Krestsoly" Nikita Ivanov of the Minor Orsha parish-led a girl. Sent a corporal and gave married. Reconciled. Mirovova with husband - $1 \mathrm{r}$. Traditional law of Mari provides a solution of such conflicts only in dowry increasing. In this connection, it is necessary to pay attention to the role of the community in the marriage. The wedding was a recognition of marriage by the society. The confirmation of it is the example, which was given by I. N. Smirnov: "In the village of Oshkatah (Lapsola) of the Vetluzhsky county, the father of the bride asks her before the blessing, are you getting married for love? And the bride says: to the people it is fine, and to me it is also fine. The bridegroom gives the same answer to the question of his future father-in-law: "are you getting married to my daughter for love?" (Smirnov, 1889). Answering so bride and bridegroom each state its total dependence on the relatives, who are the people living in the same village.

The fact of the direct intervention of a community in the household issues is the custom, which is taking place by Mari people, according to which the catched fornicators (if they were single boys or girls) were connected through the marriage, even if parents of both parties or the catched people didn't want it. Such situations were happened very seldom. So, E. I. Yakushkin noticed that "the noted by A. Efimenko custom, according to which the society sometimes forces young people to marry was earlier necessary for the economic and moral reasons, but nowdays it is absolutely destroyed" (Iakushkin, 1875). By the Mari's ethnos the marriage for those girls, who were pregnant, gave birth and broke their own chastity was perpetrated without wedding, it was only limited to a small wine party without songs and a drum. And for such girls there wasn't also a vein (Mar. "олын", "olno"). There were some cases when the pregnant girls were afraid of public scorn and they committed suicide before childbirth (Vasilyev, 1915). And they were doing it not incidentally. The unpleasant fate could wait for them and 
after the childbirth, because there were possible the self-courts over the girls who gave birth out of marriage. The severity of control from a community and the power of public opinion on observance of ethical standards didn't allow freedom of sexual communication among Maris (as well as by Russian people) out of marriage. A. A. Fuchs specified: "the behavior of the cheremissky girls is very good. They say that the unfortunate weddings are happened very seldom, in spite of the fact that some of the girls are staying single till 25 years, and the Mari boys get married too early" (Fuchs, 1840). More categorical statements we can find by L. A. Iznoskov: "The cheremis people very seldom enter into concubinage and the girl having a bond between them, is a rarity" (Iznoskov, 1869). V. M. Vasilyev confirmed on a big actual material the G. O. Mendiyarov's observation, that the debauchery "is pursued by the public opinion so strictly that it happens only as an exception. The chastity is strictly observed both in concourses and in merrymakings though the youth of both sexes takes part in them". The opposite point of view, which was given by some Soviet researchers about freedom of sexual communication between youth on a sit-round gathering can't be taken seriously. But it is impossible to affirm that this opinion is deprived of any basis. In pre-revolutionary literature we can find the instructions, that "cohabitation of women with unfamiliar people isn't pursued so much" (Kozlova, 1964).

In spite of the fact that the community role in questions of the marriages is mainly shown through the public opinion, but "if by a marriage the power of the relatives is fictitious, so by its cancellation at cheremis-pagan it is shown quite really" (Smirnov, 1889). As I. N. Smirnov noted, "for the disagreed cheremissky marrieds exists a divorce which is declared to the local rural administration before six witnesses, or on cheremissky expression, at six eyes. A divorce ceremony has its own rules: the disagreed marrieds are connected behind with a belt which is then untied, and the divorced are running into different directions; by the way some of the glibbest are sometimes trying to kick another, saying the next words: if I'm not so good for you, so look for someone, who is better" (Smirnov, 1889). That fact that "divorce of disagreed marrieds is made at six eyes, it means it is happen before six witnesses", is noted by S. V. Maximov among Volga region Maris (Maksimov, 1913). In any case it is possible to speak about that role of "the world" at implementation of divorces, which was shown in the marriages, i.e. through the traditions, which were developed in a community.

In the XVIII century polygamy was by cheremissky people an everyday occurrence (Georgi, 1799). Concerning the XVII century there is a certificate of the famous German scientist of an era of modern times by Adam Oleariya (Adam Olearius, 1727). Comparison of polygamy by cheremissky people with the fact of its existence by Tatars can direct at the assumption that the first borrowed a similar form of marriage from the last. Polygamy represents by cheremissky people the completion of a long evolutionary process. It was preceded by other, less perfect forms of a family. Their sources can be considered in the words relating to a family life, mainly in the names of relationship. The terms of relationship serve as signs of the relations existing or existing once between various members of a family and they show its initial structure. At the review of the cheremissky names of relationship first of all attracts attention the fact, that some individuals are differ between each other not on degree of blood proximity to each person, and on the age of a person. Except for the father and mother all other relatives are divided into two groups in relation to any particular person-senior and younger. If the chief of family used all women of the family, so in relation to him, naturally, the children from his wife and children from his sons' wives were equal. That and others inevitably must be divided into classes on age: if someone wanted to define the relation to people around, he called all men, who were elder-Isy (elder brothers), and all women, who were elder - elder sisters. For such role of the father or the oldest in a primitive cheremissky family, besides the given facts, also specifies that circumstance that Mari's ethnos has words only for designation of the father and the son.

In the XVIII century there were favorable conditions for development of relations with daughter in law. Then the cheremis people, according the words by F. Miller, married their sons of five and six years "with that intention that to have some more help in the homework" (Miller, 1791). At this time between the cheremis-pagan the illegitimate cohabitation of guys and girls wasn't represented as something reprehensible. Neither religious beliefs, nor the code of the developed morals didn't interfere with freedom of the relations among youth. "The cases that the girls didn't keep their chastity for the marriage, aren't rare. If the girl doesn't give way to courting, somebody catches her and make violence over her" (Miller, 1791). In the XVIII century the stealing was made like a robbery. The bridegroom with his companions was broken into the house of the bride, captured her and hurried to marry her actually still on the way going home and at witnesses. When the stealing and a purchase were replaced with the free agreement between marrying, the wife started to get property rights in the husband's family again. The recognition of these rights is visible in formulas with which parents and native of the bridegroom accompany reception of gifts from her. The teacher educator of the Mari edge of the XIX century I. A. Malyarov was written about the kozmodemyansky Mari people, that though they also got married in a church, 
but they didn't consider it as wedding and had another wedding at home according their own traditions.

The Mari marriage was allowed in all degrees of relationship and age. "10 or 12 days before the marriage of the daughter the father has fun with her and often even at the same time he gets marry her and some others, using all without thinking and without caring of, whether they are relatives with them or not" (Nicholas, 1919). As a farmer, Mari was interested in increasing of his family, in acquisition of workforce. Therefore there were cases of marriages of juvenile sons on adult girls. The custom didn't limit the man in the number of wives. Under the Oleariya's certificate, "Mari had at the same time 4 or 5 wives and didn't pay attention to the fact, that two or three of them could be sisters" (Olearius, 1727). After death of the first wife the common law allowed to marry her sister, and after this, in turn, the following sister-in-law.

In spite of the Christian religion, by the marriages Mari was guided by a common law, but not the church rules. The marriages were consisted by pagan rules. The brother lived with the brother's wife if the last was in an unknown absence. The brother widower got married the widow of the late brother. Cousins married their own sisters (Fuchs, 1840). The age of marrying people was not taken into an account. If they need a healthy, strong worker, but there were no full aged men in a family, so they got marriage the underage. The second and following marriages were allowed by the Mari common law absolutely free. Mari from the villiage Sumki of arrival of the village of Pernyagash of the Kozmodemyansky district Ivan Sidorov in 1831 declared that in April his wife was dead. "Having the house, cattle breeding, arable farming, to correct everything, both state, and worldly duties, I find myself in a great difficulty; therefore in a household and different necessary absences in working hours the peasant can't be together; no children neither man's, no female I have equally and other relatives at whom I could have an accommodation. Without having some other ways, I decided to enter second marriage, only, for keeping a house integrity, and as for me, I'd like to be free in departure of country works. I am 61 years old". The other Mari is 66 years old, he declared that in February 1831 his wife was dead. "I live in the wood for beekeeping, the son is a stupid boy; the daughter wants to marry; there is nobody to be engaged in economy of the house. I have an intention to enter the 2nd marriage". Polygamy cases among Mari were rare. Therefore the government directives about the fight against polygamy had no application here.

\section{Conclusions}

In this way, a rural community in the minds of farmers Mari performed as a traditional defender of their rights and interests. Among Mari of the Kazan County, it was called "hundred" or "hundred-town". A great difficulty was the need for claims to apply to the courts, which were in the county or in some provincial towns. Rural community was a keeper of the local traditions, at the same time it had a great influence on its members, i.e. It interfered with manifestation of a personal initiative, resisted the invasion of innovations. Most of all the community had a serious influence on the solution of questions of the household character. Its own household functions the community was realized both in the form of direct intervention in the spiritual life of peasants, and with application of economic and especially administrative and legal measures.

\section{References}

Fuchs, A. A. (1840). Notes about Chuvashia and Cheremisov Kazan province. Kazan: In type. Emperor. Kazan University.

Georgi, I. G. (1799). Description found in all the peoples of the Russian state. Their everyday practices, usages, clothing, housing, exercise, fun, memorable, and other faiths. In The History of the Russian under the Name Rousseau. Saint Petersburg: Imperial Academy of Sciences.

Iakushkin, E. I. (1875). Customary law. In A Bibliography of Customary Law. Yaroslavl: Type. Province. The Management Board.

Iznoskov, L. A. (1868). Customs mountain Cheremissian. Kazan.

Kozlova, K. I. (1964). Ethnography of the Volga. Moscow: Publishing House of the Moskovsk.

Maksimov, S. V. (1913). Edge baptized light (Coll. cit., Vol. XIX). Saint Petersburg: Enlightenment.

Miller, G. F. (1791). Description of living in Kazan province pagan nations. In Thou sho Cheremissian, Chuvashia and Votyaks. Saint Petersburg: Dependent Imp. Acad. Sciences.

Nicholas, N. V. (1919). Collection of historical materials on folk Volga. Kazan: Tipo-litogr. Kaz. University Press.

Olearius, A. (1727). Voyages tres-curieux \& tres-renommez faits en Moscovie. In Tartarie et Perse. Amsterdam.

Peretyatkovich, G. I. (1882). Volga region in the XVII century and the beginning of the XVIII century (Sketches of 
the history of colonization edge). Odessa: Type. P. A. Green.

Pushkarenko, A. A. (1984). Sense of justice of the Russian peasantry of the late feudal era. In XXVI Congress and the problems of the agrarian history of the USSR: Socio-political development of the village. Ufa: Bash. Book Publishing House.

Smirnov, I. N. (1889). Cheremis. Historical and ethnographic study. Kazan: Imperial University Printing House.

Vasilyev, V. M. (1915). Attitude to sexual promiscuity Cheremissian. Kazan: Tipo-litogr. Kaz. University Press.

\section{Copyrights}

Copyright for this article is retained by the author(s), with first publication rights granted to the journal.

This is an open-access article distributed under the terms and conditions of the Creative Commons Attribution license (http://creativecommons.org/licenses/by/3.0/). 